\title{
TRANSGRESSIONS
}

\author{
Authenticity and commercialization. \\ Cambodian theatre in a postcolonial perspective
}

\author{
Maria Delimata \\ maria.delimata@gmail.com
}

\begin{abstract}
:
The article discusses the problem of authenticity and commercialization in the context of the postcolonial theatre in Cambodia. It seems that contemporary art in this country depends on foreign funds and at the same time on the special taste of - mainly - Western donors. The author tries to show, that the epithet "pure Cambodian" is very often used to make art more interesting to tourists. A similar situation can be seen in the crucifixions in Cutud (which annually takes place in a Philippine province - Pampanga with a wide touristic audience) and in Balinese theatre (another good example of a postcolonial, hybrid identity).

Moreover, a discourse of the battle between "traditional" and "touristic" points of view does not have one answer. The search for purity can be a cause of petrifying traditional forms, as well as a sign of neocolonialism and (self-)orientalisation. On the other hand, a dialogue between indigenous artists and the others, tourists, may give the art a new profile and new meaning.
\end{abstract}

Keywords: Cambodia, Philippines, Bali, postcolonialism, theatre, authenticity, purity, commercialization.

Cambodia, French Indochina, Kâmpǔchéa, the Red Khmer - these are the words, which come to mind first, when we think about this one of the smallest, in terms of territory, country in Southeast Asia. Existing since the $1^{\text {st }}$ century AD, Cambodia was "discovered" in the $16^{\text {th }}$ century by Europeans. It was colonized first by France, then occupied by Japan and Thailand, 
then entangled in a civil war, when the Khmer Rouge killed between two to two and a half million of the inhabitants.

Colonization, conflicts, combat, genocide - all definitions which fully describe the history of many countries, but undoubtedly, they all apply to this land, which is conveniently included in the formula of "Southeast Asia" without regard to its internal diversity.

In this work, I would like to raise some questions, centred around a very large problem - the constant agon, which takes place between "authenticity" and "commercialization" of a culture. It is impossible here to present the history of Cambodia, or an in-depth study of its culture. I present only selected issues, some examples which can only begin to shed light on an extremely complex issue. An inspiration for choosing this subject was research that was conducted by C. Diamond (a professor in Soochow University and a director of the Phoenix Theater, an English-speaking theater in Taipei), described in her article Emptying the Sea by the Bucketful: The Dilemma in Cambodian Theatre (Diamond 2003).

Cambodia is only a pretext to launch into a reflection on the problem under discussion, interesting especially in the context of postcolonial countries. I would like to present two examples from other countries, which interestingly include a dialogue with the Cambodian "problem of authenticity" - the Balinese dances and Philippine crucifixion performances (balancing on a spectacular border, but in the same way having distinct elements of theatricality).

\section{The Perverse charity}

The basic problem of modern culture in Cambodia is its only apparent independence. C. Diamond shows how strongly Cambodian theatre, especially "classical dance royal" (Diamond 2003), has been entangled in political issues. In the 90s numerous international organizations (including the UN) tried to help Cambodia to reach equilibrium after years of dictatorship and the bloody rule of the Khmer Rouge. Financial support, however, resulted in reliance on these "benefactors". This is nowadays reflected in the culture.

Since 1991 Cambodia received much more humanitarian aid than any other country in Southeast Asia (Diamond 2003, p. 148). Given the fact that up to 2008 the country received up to 695 million U.S. dollars of financial aid, mostly from countries which supported the efforts to overturn the regime (http://cambodiamirror.wordpress.com/2007/06/21/thursday2162007-cambodia-receives-foreign-aid-of-more-than-689-million-for-development-in- 
2008/), we can observe, that this activity - instead of being scaled down - is constantly growing.

Indeed, Cambodia fell into a trap that consists primarily on the market mechanism: Western benefactors (especially from France and the United States) most value classical dance, so in the same way they spend the largest sums of money to watch and to develop it. Indeed the most heavily funded, this branch of art is the most popular (and thus - it earns for itself the largest investment), also the support from the government (which has funds transferred by Western countries) is targeted primarily to schools and theatres, where the court theatre is developed and shown.

\section{The hybrid}

It is worth briefly describing this - probably for many people very mysterious and little-known - type of theatre. Robam kbach boran (literally meaning "Khmer dance in ancient style"; the name was changed in the 80s, so in the time of Lon Nol's regime - the earlier definition was used: robam preah reachea trop, meaning "dances of royal wealth") is a form of dance/ballet, probably dating back to the time of Angkor dynasty (802-1432 AD).

The importance of Apsara dances ${ }^{1}$, and the entire culture of the Angkor times, can be clearly seen in its inclusion on the UNESCO list of world heritage. It was also commemorated on coins from Cambodia significantly having the name "seven wonders of the world" (Wiśniewska 2009). In antiquity the name of the dance/theatre was adopted "for the determination of the temple dancers who performed dances at the funerals of kings and also at times when they implore the grace of the gods" ${ }^{\text {"2 }}$ (Wiśniewska 2009). The $19^{\text {th }}$ century was a time of important innovation (especially of the dancers' costumes), because it was then that King Ang Duong decided, under the influence of his stay at the court in Bangkok, to make Apsara dance more similar to Thai dances. In the $20^{\text {th }}$ century French travellers, who came to Cambodia, were so delighted by this theatrical form, that they decided to organize performances of Cambodian dancers in Paris. This was immortalized in Auguste Rodin's paintings.

Robam kbach boran requires a perfect mastery of their bodies by the dancers. History portrayed in the dance is expressed through a complex kinetic action. Extremely ornate costumes and plenty of jewellry, mostly gold, as well as specific headgear (to help viewers to

\footnotetext{
${ }^{1}$ All the information about Apsara dances can be found in B. Wiśniewska's article Siedem cudów świata-taniec Apsara (Wiśniewska 2009).

${ }^{2}$ Translated by M. Delimata.
} 
identify specific characters) are very characteristic. There are four main types of characters: neay rong (men), neang (women), yeak (ogres) and sva (monkeys). Significantly - both neay rong and neang - are played by female dancers.

This form of theatre was performed primarily by artists closely associated with the court, therefore, during the regime of the Khmer Rouge it was considered to be "too aristocratic". Moreover, during the first four years of the regime about $90 \%$ of the dancers were killed. Probably for this reason, after the events of 1991, the restoration of the strong position of "royal form" has become one of the priorities for the new government. Entanglement in politics is evident, therefore, not only in the way of funding the theatre, but also purely at the ideological level.

Hybridity - to use Homi Bhabha's term - interestingly describes the nature of contemporary Cambodian art. However, it also seems important to show the influence of Western culture. Lakhaoun niyeay may be the most meaningful example. This spoken drama is very strongly inspired by Western realism - though its sources are likely to be found also in another Cambodian form - sbek touch (Diamond 2003, p. 166). In the time of French colonization it was under strict control and censorship, especially because of its exploration of political issues.

Hybridity emerges, however, not necessarily on the line Cambodia-France/West, colonized-colonizer. In theatre forms such as yike (traditional dance, based on a drama) whether the currently more popular bassac (musical drama, formed mainly under the influence of Vietnam culture), we can see a very strong influence of neighboring cultures Thailand, Vietnam, but also India and China. According to many researchers, Khmer court dance can be a transposition of Thai dances (Wiśniewska 2009), and yet even the pillar of this form - gestures - recalls the foundation of Indian theatre.

\section{The tourist's starvation}

Research conducted in the second half of the nineteen-fifties (Diamond 2003, p. 154) shows that among "ordinary" Cambodians folk drama is the most popular. It combines elements of comedy and improvisation. It is not enough, however, that the group showing that kind of theatre (understood differently than in the tradition of European or American), were as competitive as, for example, artists creating robam kbach boran.

This situation stems not only from the fear of losing significant funding sources. Not meeting certain artistic preferences threatens mainly the deterioration of the tourism sector. 
A. Wieczorkiewicz in The tourist appetite. The experience of the world in travel shows that tourism "for some people is the invasion of barbarians, for others is a contemporary ritual. Some see it as a commercial venture, while others as an area of intercultural encounters. It appears as an integral part of lifestyle, sign of social status and a form of therapy..." (Wieczorkiewicz 2008, p. 5).

Thus we encounter here another problem - the ambivalent tourist's perspective, also that particular one, who could be a viewer of a performance prepared by students and teachers of the Royal University of Performing Arts in Phnom Penh. Is the barbarous tourist, who will never be able to fully understand the foreign cultural code - but becomes the recipient of a performance - making authenticity invisible? Perhaps the "form of therapy" includes not only the touristic audience, but also the indigenous people, giving the art a new profile and new meaning.

As we can see, the economic entanglement associated with tourism can also have positive implications. The article by S. Yamashita Tourism and the creation of culture: case in Bali, Indonesia, and Tono, Japan surprises by its innovative perspective of discussing the problem of modern tourism. "The invasion of the barbarians" turns out to be not only destructive, but rather as challenging, and encourages an impulse for the development of culture. According to S. Yamashita: "nowadays culture cannot be cut off from such phenomena as »globalization«, »creolization«, »fragmentation«, »deterritorialization« and »commodization«. Tourism is good example for examining »the cultural logic of late capitalism «" (Yamashita 1995, p. 112).

Thanks to tourism the culture in some countries of Southeast Asia is becoming more essential. This would not be possible without such forms of contact. "Tourism in both cases has actually reactivated traditional culture rather than damaged it" (Yamashita 1995, p. 116). Tradition transformed by tourism, according to Yamashita, depends on the regional, national and even global perspective. Moreover, it is postmodern, and therefore appears as a reconstruction of some elements of culture, mainly in the context of tourism (Yamashita 1995, p.116-117).

C. Diamond describes an artist, whom she places in the alternative part of Cambodian culture. M. Kosal, an artist, became famous for his nonconformist relation to the situation of theatre art in Cambodia. From the 90s M. Kosal concentrated his work on a form of shadow theatre virtually forgotten in the period of the Khmer Rouge. This playwright, director, choreographer, and above all - the master of the Cambodian puppet theater, tried not only to 
renew the traditional theatrical form. His nearly two decades of studies on this subject, combined with talent and original approach to art, brought him worldwide popularity. In contrast to the classical dance form, M. Kosal worked with a form so familiar to "ordinary" Cambodians. Moreover, his success had a measurable effect in terms of building his own theatre building, which somehow mitigates the very pessimistic vision shown in the first part of C. Diamond's article. Thus we see the possibility of development of the "unpopular" art in its "popularity".

C. Diamond, in the context of the current situation in Cambodia, speaks directly about "culture of dependency" - in line with financial dependence goes a more and more confused Cambodian national identity. Only this type of art achieves an opportunity for development, which appeals to those who have funds. Philanthropy becomes here a very gracious and often perverse patronage.

\section{Purity?}

Authenticity, often demanded in Asian art by its creators, as well as some foreign audiences, is usually associated with purity. This concept refers to some ideal being toward which man can strive, but can never be sure to fully reach. Purity is constituted through the relationship with its negation - dirt, or as proposed by M. Douglas, the slur. Dirt, as well as cleanliness, for the British social-anthropologist are related to the "cleanup, normative operation of the culture, all the cultures" (Tokarska-Bakir 2007, p. 8). It constructs the taboo, which is "a spontaneous instrument for the protection of distinctive categories of the universe. [...] It reduces the intellectual and social disorder" (Tokarska-Bakir 2007, p. 9). Purity is therefore the guarantor of order, a promise of a refuge. Nevertheless, it is too often forgotten that it belongs to the realm of ideas (rooted in a reality, made by man, but still being a subjective construction), and therefore treating it as the highest court in the judgment on the value of a given culture is going into a blind alley.

Here we enter into the debate on art at a much more universal scale, unlimited by the category of nationality. P. Bourdieu pointed out, that setting the boundary between avantgarde art, a "pure" one, and the other, subjected to commercialization, is extremely smooth and dichotomist (Bourdieu 1996). The author of The Rules of Art examines the process, which has taken place in Europe since the $19^{\text {th }}$ century to the present - to the birth of commercial culture, which had to face the avant-garde art. Especially the late $19^{\text {th }}$ century abounded in a constant struggle between "pure art", the liberal one - at least for some time - with the aim to 
achieve maximum financial gain. P. Bourdieu, however, combats the myth of "unadulterated art", indicating that the fields of market and anti-market always compete with each other.

That unillusive analysis - in the context of the European art - can become an inspiration for thinking about culture from other parts of the world. In the case of a postcolonial country we see also another, difficult problem - the injuction of "pure art" may be a neocolonialism as well as financial manipulation of some of its branches. Perhaps we see here the kind of hidden, but highly effective (self-)orientalisation. Searching the pre-colonial elements, for example "pure Cambodian", may be a destruction of the fact of colonization. The culture remains alive as long as it changes and is continually updated under the influence of contemporary history.

R. Schechner, in his excellent article Wayang kulit in the colonial margins, shows that one of the most famous forms of Javanese theatre is in fact "the product of collaboration between the courts and colonial Dutch scholars" (Schechner 1995b, p. 193). Demanding nowadays "»the purity« of the normative expectation is a strategy not only to drain the politics from wayang, to freeze it in »authenticity« and nonmodernity, but to conceal the Dutch colonial presence and the Javanese responses to it" (Schechner 1995b, p. 186).

Hunting for purity can be a path leading nowhere. It does not struggle to maintain authenticity, but rather is the cause of petrifying forms. Worse, it often works to distort the postcolonial history.

\section{Authenticity?}

The question which has to be asked is how we conceive of authenticity. Can art - in its very essence being condemned to be artificial - be authentic? Do we have the right to formulate benchmarks axiologizing an artistic form - human work, set in a specific time and specific space?

There is no way to escape the category of mimesis, which has been present in human culture since the time of Aristotle. Mimesis, which perpetually flickers between reality and fiction, artifice and veracity. Perhaps post-colonial culture should be examined in terms of "disenchanted mimesis". What the colonists meant as authenticity (often associated with pejorative, uncivilized primordial concept), escaped from their supremacy - unfortunately, sometimes frightening by its caricature even postcolonial people.

Is yike (traditional theatrical and dramatic form), prepared in the evenings after work in the field by a small Cambodian village community for their fellow citizens "more authentic" 
than that one shown to several hundred people (often international audiences) in the airconditioned theatre in the centre of Phnom Penh? Clearly new quality - obtained under the influence of tourism - did not lead to destruction.

It is difficult to disagree with the argument that the struggle for recovery, or rather for finding identity - through art - is a very positive movement. However, dependence on the Western taste and "touristic" audience might be entering into a blind alley. Working to save the independence and originality should be a priority in every artistic activity. Back to the roots - especially after several hundred years of being colonized - is first of all a form of exploration and constitution of national identity.

On the other hand we cannot ignore the status quo. Tradition, culture and art always remain under the strong influence of history or politics. Back to the roots, which in practice would mean the destruction of tens or hundreds of years of the particular tradition (also theatrical) recalls the demolition of architecture built in times which are now considered "politically incorrect". Such a return to sources carries with it a dangerous element of destruction.

The primary problem which contemporary Cambodia must face is a struggle for independence and development. In my opinion it does not mean searching for authenticity made immaculate by marketing, or elimination of foreign audiences, instead finding a compromise between the current political and economic situation and expectations of artists and the wider public.

\section{Comparisons}

\section{Philippines ${ }^{3}$}

Enacted crucifixions, which take place every year during Holy Week in a small village Cutud in Pampanga province, have become one of the most recognizable images of the Philippines. This tradition probably goes back to precolonial times (before $16^{\text {th }}$ century), but it is the activity of the Spanish missionaries who brought the greatest development to this annual event, thus bringing them closer to self-flagellations formerly held in Europe.

Crucifixions, in the form in which we see them today, developed in the $20^{\text {th }}$ century, when Artemio Añosa decided to reinforce his current panata - instead of playing in sinakulo (locally organized passion) the Christ on the cross, he decided to truly nail his body in a performance.

\footnotetext{
${ }^{3}$ According to my research conducted in the Philippines in November 2008-April 2009.
} 
It is worth explaining this foreign word, which in fact conceals the meaning of any religious practice in the Philippines - and therefore is also the most drastic - and thus the most recognized manifestations of flagellations and crucifixions. Panata means a sacrifice, taking specific steps to mollify God, asking him to make desires come true. Once taken up it must be completed. Therefore it often happens that a family member takes on panata from a person who decided to start but cannot continue it. Thereby, the existing community is more consolidated.

It is often hard to value the Philippine crucifixions, because of some images of this event - especially from a foreign outlook. On the one hand, visitors in kalbaryo meet dozens of cameras set on giant scaffolds, which transmit the crucifixions to the whole world. What is more, every performer, Kristo, has an uncovered face. This is in contrast to self-flagellants and therefore often the pictures are published in the most popular newspapers and magazines in the world. Also the binding of the spectacle itself raises a distaste for some people. It is not rare to see some performers in the crowd falling because of the pain and just next to them a noisy ice-cream barrow or a whip-seller pedling his wares. Cultural similarities should be remembered - do European fairs, organized during the holy time of pilgrimage, not recall the atmosphere in Cutud?

However, this is only one way to look at this event. Although commercialism, incredibly developed since the 80s (the time when crucifixions first drew media attention), is clearly visible at every step, it is only part of the answer to the question of how to describe this event. Answers may also be found in a very strong pillar of that culture - Philippine religiosity, rooted primarily in the community, as well as in personal contact with God and a little less dependent on the opinion of the Catholic Church. Despite the many controversies due to the "commercial esthetic" of the spectacle, for many performers it is still one of the most difficult and the most important events in their lives. Faith through suffering gives them strength to perform superhuman feats.

However, it seems very interesting, that this formerly modest, local performance has developed and became so important both the domestic and foreign media. Even the largest companies - such as Coca-Cola -begin the battle every year to get an opportunity for advertising their products throughout the town visited by hundreds (sometimes thousands) of tourists. Money, however, is not called "payment", but rather "donations" - mainly by Rolando Navarro, the current "director" of the group, which prepares the performance of crucifixions - moreover he is a son of Ricardo Navarro, the author of the foundation for the 
sinakulo Via Crucis o Pasion y Muerte - "Way of the Cross or Passion and Death" (Tiatco, Bonifacio-Ramolete 2008, p. 67).

Commercialization constantly interlaces with authenticity. Tourism is developing that religious performance, but at the same time it permanently changes the nature of the event. The local accent must yield to the global one. But do we have the right to call the crucifixions just a cheap entertainment for the delight of rabble? Looking at the face of crossed Kristo, at every muscle in a whipped body falling down because of the pain, it is hard to believe that desire for profit and fame are the only reason for this event. Panata still belongs to the sacred sphere.

\section{Bali}

A perspective proposed by S. Yamashita seems to be very relevant to this discussion. In his article he describes the situation in Bali, one of the most famous islands in Indonesia. This island in the 30s became "Eden" for Western anthropologists. Scholars and - what is important in this context - also artists, were going to Bali in search of delicate and delightful (especially in context of being so "oriental") theatre. The researchers - often with undeniable value - were such as C. Geertz, J. Belo or M. Mead.

The problem that S. Yamashita primarily exposes is the entanglement of "authenticity" (or what Western seekers would like to call by this name) in tourism. Indeed, the tourism, which, as it converts, also sometimes degenerates, as well as develops the culture. The glory has brought Bali not only an important place in Western science, but also permanently changed its own face. Bali perceives its own differences mainly by contact with the Other, but also with those who suddenly become a recipient of the art and are therefore always forced to renegotiate the status of their identity.

S. Yamashita writes also about the impact of tourism on the formation of a new form of "nationalism" in Indonesia. It means a national project The Visit Indonesia in 1991, which provides, inter alia, a specific calendar of artistic events, and promoting a regional culture most popular among tourists (Yamashita 1995, p. 114).

In the case of Bali, there did not exist only a presentation of their culture to foreign audiences. Indeed, it was about a much more complex and deeper issue: a dialogue. Contact with Western artists and researchers, who often stayed for a long time on the Indonesian island learning from the local artists, has meant that the modern culture of this place should be considered now in the category of hybridity. 
Maybe "the last paradise on the earth" has become a lost paradise? Perversity of this question is just another pretext for discussion of authenticity associated with the category of purity.

\section{Where are we headed?}

The fight between authenticity and commercialization, which is going on all the time, will never end. Tourism - constantly and vigorously developed and at the same time so ambivalent (this has been illustrated by two extreme positions: Diamond with Yamashita and Wieczorkiewicz) - can be a sign of the times. It seems impossible to fully and satisfyingly answer the question of what in fact "purity", "truth" and "anti-commercialism" are. Although authenticity has been one of the biggest obsessions of modern humanity (Warchała 2006), it also demands recognition of its existence in the post-modern world.

Culture has always been and of course will continue to be, not only in the increasingly globalized world, embroiled in politics but also on the economic (including a touristic perspective) and ideological levels. On the other hand, the work of artists and their art, and sometimes their faith, ensure survival for art forms regardless of the circumstances in which they will be performed.

In the context of a dialogue between postcolonial countries and their former colonizers, we have to remember about the "colonial bath" which, according to R. Schechner, everyone experienced, indeed every person in the world (Schechner 1995b, p. 222). Contemporary reality demands to be demythicized. We need to be conscious that even "the notion of "traditional« is itself a product of colonialism" (Schechner 1995b, p. 224). This applies not only as described here with the examples of Cambodia, the Philippines, Bali, and Java, but indeed to the whole postcolonial world - East, West, South or North.

Every one of the standpoints presented here may be in the same way right as well as wrong. Certainly many of the questions raised here may sound controversial. The aim of this paper, however, is not to find an easy answer, nor to draw a map that would safely grant us passage through the dark labyrinth. For matters related to culture (and thus at the same time: to politics, tourism, economy), the most important objective may not be to reach the end of this labyrinth, but rather to depart on the way leading inside.

\section{Bibliography:}


Bourdieu P. (1996), Rules of Art: Genesis and Structure of the Literary Field, Emanuel S. (trans.), Stanford University Press, Chicago.

Diamond C. (2003), Emptying the Sea by the Bucketful: The Dilemma in Cambodian Theatre, "Asian Theatre Journal” 20 (2).

Douglas M. (2007), Czystość i zmaza, Bucholc M. (trans.), Państwowy Instytut Wydawniczy, Warszawa.

Schechner R. (1995a), The future of ritual: writings on culture and performance, Routledge, London.

Schechner R. (1995b), Wayang kulit in the colonial margin, [in:] Schechner R., The future of ritual: writings on culture and performance, Routledge, London.

Tiatco S.A.P., Bonifacio-Ramolete A. (2008), Cutud's Ritual of Nailing on the Cross: Performance of Pain and Suffering, "Asian Theatre Journal" 25 (1).

Tokarska-Bakir J. (2007), Energia odpadków, [in:] Douglas M., Czystość i zmaza, Bucholc M. (trans.), Państwowy Instytut Wydawniczy, Warszawa.

Warchała M. (2006), Autentyczność i nowoczesność. Idea autentyczności od Rousseau do Freuda, Universitas, Kraków.

Wieczorkiewicz A. (2008), Apetyt turysty. O doświadczaniu świata w podróży, Universitas, Kraków.

Yamashita S. (1995), Tourism and the creation of culture: case in Bali, Indonesia, and Tono, Japan, Toyota Foundation, Tokyo.

\section{Netography:}

Cambodia Receives Foreign Aid of More Than $\$ 689$ Million for Development in 2008, “The Mirror" 11 (513), http://cambodiamirror.wordpress.com/2007/06/21/thursday-2162007cambodia-receives-foreign-aid-of-more-than-689-million-for-development-in-2008/, retrieved: 11.10 .2009 .

Wiśniewska B. (2009), Siedem cudów świata - taniec Apsara, http://www.emonety.pl/page/siedem-cudow-swiata-8211-taniec-apsara-p628.html, retrieved: 22.11.2009. 